\title{
Elder abuse: The role of general practitioners in community-based screening and multidisciplinary action
}

Nola M Ries, Elise Mansfield

\section{Background \\ There are growing calls for elder abuse screening to be conducted by a range of community-based service providers, including general practitioners (GPs), practice nurses, home care workers and lawyers. Improved screening may be a valuable first step towards improving elder abuse detection and response; however, practitioners need evidence- based strategies for screening and follow-up.}

\section{Objective}

This article summarises several brief screening tools for various forms of elder abuse. Screening tool properties and evidence gaps are noted. As elder abuse often requires multidisciplinary responses, initiatives to connect health, legal and other service providers are highlighted.

\section{Discussion}

GPs are trusted professionals who are well placed to identify older patients at risk of, or experiencing, various forms of abuse. They should be aware of available screening tools and consider how best to incorporate them into their own practice. They also play an important role in multidisciplinary action to address elder abuse.
THE ABUSE OF OLDER PEOPLE in OUr communities is a serious and underdetected problem. In its various forms - emotional, financial, physical, sexual, neglect - abuse has profound individual and social impacts, depriving older people of their assets and increasing their risk of injury, hospital admission, residential care placement and premature mortality. ${ }^{1}$ Physicians have a 'pivotal role' in screening, assessment and management, ${ }^{2}$ but they cannot do it alone. In a recent report on elder abuse, the Australian Law Reform Commission stressed that elder abuse is 'everybody's responsibility - a responsibility not only to recognise elder abuse, but most importantly, to respond to it effectively'. ${ }^{3}$ Multidisciplinary approaches are needed to identify and assist older people at risk of, or experiencing, different types of abuse. The coordinated involvement of health, legal and community service providers is considered the 'gold standard for programs, policies and practices, as no single discipline or sector alone has the resources or expertise needed to address the issue'. ${ }^{4}$

\section{Screening in community settings}

To offer appropriate supports to older people, situations of concern must first be identified, and there are growing calls for routine elder abuse screening in community settings. ${ }^{5}$ Many submissions to the Australian Law Reform Commission and a 2016 New South Wales government inquiry into elder abuse advocated that abuse screening be conducted not only in healthcare settings, but by others who interact with older people, including home care workers, lawyers and financial institution employees. ${ }^{3,6}$

The emphasis on wider screening has three key implications for general practitioners (GPs). First, they should know about available screening tools and consider how best to incorporate them into their own practice. Second, they should be aware that a growing range of service providers may identify potential situations of elder abuse and make contact with the GP to request assessments. Third, doctors and staff in general practices need links with other service providers who can assist older people with the legal, financial and social aspects of abusive situations.

\section{Elder abuse screening tools}

Several screening tools have been developed to assist communitybased service providers in identifying older people who are at risk of, or are experiencing, abuse. Five tools and their key characteristics are summarised in Table 1 . We focus on only those tools that are suitable for community settings, do not require specialised training, and involve direct questioning of the older adult, given the inconsistency between self-reported and provider-reported outcomes. Three tools explore vulnerability across all categories of abuse, and two more recently developed tools focus on screening specific to financial exploitation, a prevalent form of abuse 'that may be detected or suspected by an alert physician'. ${ }^{7}$ All tools were developed to be administered verbally, most in around five minutes. It may be possible for the older adult to complete at least some sections of these questionnaires 
on paper or an electronic device while, for example, waiting for their appointment.

Affirmative responses to questions indicate a need for further discussion with the patient. One tool, the six-item Elder Abuse Suspicion Index, was developed for use in primary care settings. It is designed to guide physicians in establishing when to discuss with their patients referrals to community services, such as legal help, specialist elder abuse organisations, and home and aged care supports. These screening tools offer standardised approaches that can aid in initiating conversations; however, physicians should be aware of their current limitations. No studies have examined their acceptability to older people, and this is a serious evidence gap that must be remedied. ${ }^{5}$ The psychometric properties of most of these tools require further testing, particularly as the sensitivity and specificity of most tools is limited. Most tools have not been validated with older adults with cognitive impairment, a group that is likely to be especially vulnerable to abuse. Only one of the tools was developed and tested in Australia. The applicability of other tools to the Australian context is yet to be evaluated.

\section{Incorporating screening into practice}

While the development of high-quality screening tools may improve the identification of elder abuse, providers need to be willing to use these tools in their practice. Providers identify a number of barriers to undertaking regular screening, such as a lack of skills or confidence, perceived harms to the patient-provider relationship, and uncertainty about actions to take in the event that abuse is suspected. A 2016 systematic review states that 'one of the most central areas for intervention is in the education and training of professionals responsible for the prevention of elder maltreatment'. ${ }^{8}$ A developing body of literature offers recommendations and resources, ${ }^{9}$ including strategies aimed at helping novice providers improve their confidence and skills in screening. ${ }^{10}$ Professional development that educates physicians and other health practitioners about social and legal issues and resources increases their willingness to broach sensitive topics with their patients. ${ }^{11}$

Screening should be approached with the goal of building a therapeutic alliance with older patients, ${ }^{12}$ emphasising concern for their safety and wellbeing, and assisting patients with information and supports to make their own choices in accordance with their interests and values. ${ }^{13}$ The Australian Law Reform Commission articulates key principles:

Older people, like most adults, prize their freedom and independence, and do not wish to be treated like children or sheltered from all risk. The autonomy of older people should not be afforded less respect than the autonomy of others. However, in limited cases, where there is particularly serious abuse of vulnerable people, protection should be given additional weight. ${ }^{3}$

According to a recent Victorian report on elder abuse interventions, older people who received help to deal with abusive situations urge service providers, including doctors, to provide earlier referrals and supports when abuse or risk factors are identified. ${ }^{14}$ Where abuse occurs within families, maintaining relationships is often an important goal for older parents and they seek resources for their adult children whose abusive behaviours arise from mental health, drug or alcohol problems. ${ }^{14}$

Even where screening reveals no immediate concerns for older patients, these conversations create an opportunity for physicians to educate patients on risk factors for abuse and discuss prevention strategies. This can include discussion of enduring appointments, which enable patients to choose trusted people who will act as their decision makers for health, financial and other personal matters in periods of incapacity. In theory, these appointments are tools of self-determination for older people; in reality, they can be tools for abuse, and patients need guidance on making suitable appointments. ${ }^{3}$ General practices can have an important role in providing information on community services, such as elder abuse helplines, specialist seniors' rights legal centres, and public trustee offices. This information can equip older patients with knowledge of where to access expert help if and when needed for themselves or their peers.

\section{Multidisciplinary action}

To achieve the 'gold standard' of multidisciplinary interventions, new approaches are needed to connect community service providers and strengthen physicians' ability to support patients at risk of, or experiencing, abuse. For example, the Queensland Law Society and the Australian Medical Association of Queensland are collaborating on a trial involving GPs and staff at over 300 clinics to enhance recognition of elder abuse and facilitate referrals to lawyers and other services where necessary. ${ }^{15}$

The authors are co-leading a pilot study in a regional area of New South Wales that aims to improve detection and support for older adults who are at risk of, or are experiencing, abuse. Funded by the NSW Department of Family and Community Services, the project brings together practitioners in health, aged care and legal sectors for interprofessional education on elder abuse, training in the use of a screening process to identify situations of concern, and referral pathways for follow-up actions. Qualitative data will be collected following a pilot screening period and used to inform further work on community-based screening and multidisciplinary collaboration.

Health-justice partnerships offer another promising approach to supporting older people experiencing abuse. ${ }^{16}$ By integrating lawyers into healthcare settings, such partnerships offer coordinated services to meet older patients' intersecting health and legal needs and enable timely access to help when screening identifies a problem. In Victoria, for example, a collaboration between a pro bono legal service and a community health organisation in Melbourne has focused on improving timely identification and supports for older clients experiencing abuse. ${ }^{17}$

General practice settings are important sites for research, to understand patient 


\section{Table 1. Elder abuse screening tools suitable for use in community settings using direct questioning of the older adult}

\begin{tabular}{|c|c|c|c|}
\hline $\begin{array}{l}\text { Measure name } \\
\text { Country in which tool developed } \\
\text { Administration method } \\
\text { Completion time } \\
\text { Used in Australian studies? }\end{array}$ & $\begin{array}{l}\text { Number of domains, types of } \\
\text { abuse and items }\end{array}$ & $\begin{array}{l}\text { Timeframe over which risk } \\
\text { assessed } \\
\text { Response scale }\end{array}$ & Psychometric properties \\
\hline $\begin{array}{l}\text { Elder Abuse Suspicion Index } \\
\text { (EASI) } \\
\text { Canada } \\
\text { Interview conducted by primary } \\
\text { care provider } \\
\text { 1-10 mins } \\
\text { Not used in Australian studies }\end{array}$ & $\begin{array}{l}\text { Domains: } \\
\text { - Risk for abuse (one item) } \\
\text { - Abusive behaviours (five items) } \\
\text { Types of abuse: Emotional, } \\
\text { physical/sexual, financial, neglect } \\
\text { Items: } 6\end{array}$ & $\begin{array}{l}\text { Past } 12 \text { months } \\
\text { Five Yes/No questions asked } \\
\text { of the patient } \\
\text { One Yes/No question asked } \\
\text { of the provider }\end{array}$ & Relatively low sensitivity \\
\hline $\begin{array}{l}\text { Hwalek-Sengstock Elder Abuse } \\
\text { Screening Test (HS-EAST) } \\
\text { US } \\
\text { Self-administered interview } \\
\text { 5-10 mins } \\
\text { Not used in Australian studies }\end{array}$ & $\begin{array}{l}\text { Domains: } \\
\text { - Violation of rights or direct } \\
\text { abuse } \\
\text { - Traits that increase } \\
\text { vulnerability } \\
\text { - Features of potential abusive } \\
\text { situations } \\
\text { Types of abuse: Emotional, } \\
\text { physical/sexual, financial, neglect } \\
\text { Items: } 15\end{array}$ & $\begin{array}{l}\text { Time frame not specified - } \\
\text { focused on current experiences } \\
\text { Response scale: Yes/No }\end{array}$ & $\begin{array}{l}\text { Acceptable content, } \\
\text { criterion, construct validity } \\
\text { High false-negative rate }\end{array}$ \\
\hline $\begin{array}{l}\text { Vulnerability to Abuse Screening } \\
\text { Scale (VASS) } \\
\text { Australia } \\
\text { Self-administered interview } \\
5-10 \text { mins } \\
\text { Used in an Australian study }\end{array}$ & $\begin{array}{l}\text { Domains: } \\
\text { - Vulnerability } \\
\text { - Dependence } \\
\text { - Dejection } \\
\text { - Coercion } \\
\text { Types of abuse: Emotional, } \\
\text { physical/sexual, financial, neglect } \\
\text { Items: } 17 \text { (consists of the } \\
\text { HS-EAST scale with two } \\
\text { additional items) }\end{array}$ & $\begin{array}{l}\text { Time frame not specified- } \\
\text { focused on current experiences } \\
\text { Response scale: Yes/No }\end{array}$ & $\begin{array}{l}\text { Moderate to good internal } \\
\text { consistency reliability } \\
\text { Acceptable construct } \\
\text { validity } \\
\text { Positive correlations with } \\
\text { abuse risk factors }\end{array}$ \\
\hline $\begin{array}{l}\text { Lichtenberg Financial Decision } \\
\text { Making Screening Scale (LFDSS) } \\
\text { US } \\
\text { Self-report questionnaire } \\
\text { administered via interview } \\
\text { 5-7 minutes } \\
\text { Not used in Australian studies }\end{array}$ & $\begin{array}{l}\text { Domains: } \\
\text { - Intellectual factors } \\
\text { - Susceptibility to undue } \\
\text { influence } \\
\text { Types of abuse: Financial only } \\
\text { Items: } 10\end{array}$ & $\begin{array}{l}\text { Refers to a financial transaction } \\
\text { currently in process of making } \\
\text { or already made } \\
\text { Response options variable } \\
\text { depending on question }\end{array}$ & $\begin{array}{l}\text { Acceptable internal } \\
\text { consistency reliability } \\
\text { Acceptable criterion } \\
\text { validity }\end{array}$ \\
\hline
\end{tabular}

EASI: Yaffe MJ, Wolfson C, Lithwick M, Weiss D. Development and validation of a tool to improve physician identification of elder abuse: The Elder Abuse Suspicion Index (EASI). J Elder Abuse Negl 2008;20(3):276-300. HS-EAST: Sengstock M, Hwalek, M. A review and analysis of measures for the identification of elder abuse. J Geron Soc Work 1987;10:21; Neale AN, et al. Validation of the Hwalek-Sengstock Elder Abuse Screening Test. J Appl Gerontol 1991;10:406-18. VASS: Schofield MJ, Mishra GD. Validity of self-report screening scale for elder abuse: Women's Health Australia Study. Gerontologist 2003;43(1):110-20. OAFEM: Conrad KJ, et al. Self-report measure of financial exploitation of older adults. Gerontologist 2010;50(6):758-73. LFDSS: Lichtenberg PA, et al. The Lichtenberg Financial Decision Screening Scale (LFDSS): A new tool for assessing financial decision making and preventing financial exploitation. J Elder Abuse Negl 2016;28(3):134-51. 
and practitioner perspectives on elder abuse, to trial multidisciplinary collaborations, and to investigate the impact of screening and interventions on improved outcomes for older people. Funding for innovative models of service delivery should support robust evaluation strategies to determine their impact on identifying, managing and preventing elder abuse. ${ }^{18,19}$

\section{Conclusion}

Routine, community-based screening in general practices and other settings may be a valuable first step towards improving elder abuse detection and response. More work is needed to identify a reliable screening tool that is acceptable to primary care practitioners and their patients, and to investigate barriers and enablers to its use. In adopting screening processes and responding to situations of concern, practitioners should support and empower patients to make decisions in line with their values and goals. ${ }^{20}$

\section{Authors}

Nola M Ries JD, MPA, LLM, Associate Professor, Core Member, Law, Health, Justice Research Centre, Faculty of Law, University of Technology Sydney, NSW.nola.ries@uts.edu.au

Elise Mansfield PhD, Postdoctoral Research Associate, Health Behaviour Research Collaborative, School of Medicine and Public Health, Faculty of Health and Medicine, University of Newcastle, NSW Competing interests: None.

Provenance and peer review: Not commissioned, externally peer reviewed.

Funding: The authors acknowledge funding support from the New South Wales Department of Family and Community Services.

\section{References}

1. Wang XM, Brisbin S, Loo, T, Straus S. Elder abuse: An approach to identification, assessment and intervention. CMAJ 2015;187(8):575-81. doi: 10.1503/cmaj.141329.

2. Australian Medical Association. AMA position statement on care of older people 1998 Amended 2000 and 2011. WA: AMA, 2011 Available at https://ama.com.au/sites/default/ files/documents/AMA_position_statement on_care_of_older_people_2011.pdf [Accessed 15 February 2018].

3. Australian Law Reform Commission. Elder abuse - A national legal response (ALRC Report 131). NSW: ALRC, 2017. Available at www.alrc.gov.au/ publications/elder-abuse-report [Accessed 23 September 2017].

4. Du Mont J, Kosa D, Macdonald S, Elliot S, Yaffe M. Determining possible professionals and respective roles and responsibilities for a model comprehensive elder abuse intervention: A Delphi consensus survey. PLoS One 2015;10(12):e0140760. doi: 10.1371/journal. pone.0140760.

5. Gallione C, Dal Molin A, Cristina FVB, Ferns H, Mattioli M, Suardi B. Screening tools for identification of elder abuse: A systematic review. J Clin Nurs 2017;26(15-16):2154-76. doi: 10.1111/ jocn.13721.

6. Parliament of New South Wales, General Purpose Standing Committee No 2. Elder abuse in New South Wales. Sydney: Legislative Council, June 2016. Available at www. parliament.nsw.gov.au/committees/inquiries/ Pages/inquiry-details.aspx?pk=2387\#tabreports [Accessed 10 July 2017].

7. Lachs MS, Pillemer KA. Elder abuse. N Engl J Med 2015:373(2):1947-56. doi: 10.1056/ NEJMra1404688.

8. Ayalon L, Lev S, Green O, Nevo U. A systematic review and meta-analysis of interventions designed to prevent or stop elder maltreatment. Age Ageing 2016;45(2):216-27. doi: 10.1093/ ageing/afv193

9. Harries P, Gilhooly M, Gilhooly K, Davies MS Enhancing workforce capacity in the detection and prevention of elder financial abuse. Public Policy \& Aging Report 2016;26(1):30-33.

10. Harries P, Davies M, Gilhooly K, Gilhooly M, Tomlinson C. Educating novice practitioners to detect elder financial abuse: A randomised controlled trial. BMC Med Educ 2014;14:21. doi: 10.1186/1472-6920-14-21.
11. O'Toole JK, Burkhardt MC, Solan LG, Vaughn L, Klein MD. Resident confidence addressing social history: Is it influenced by availability of social and legal resources? Clin Pediatr (Phila) 2012;51(7):625-31. doi: 10.1177/0009922812438081.

12. Burnes D. Community elder mistreatment intervention with capable older adults: Toward a conceptual practice model. Gerontologist 2017;57(3):409-16.

13. NSW Government, Family and Community Services. Preventing and responding to abuse of older people: NSW interagency policy. NSW: NSW Govt, November 2015. Available at www. elderabusehelpline.com.au/uploads/pdf/FACSNSW-Interagency-Policy-updated-November-2015 pdf [Accessed 23 September 2017].

14. National Ageing Research Institute (NARI)/ Senior's Rights Victoria (SRV). The older person's experience: Outcomes of interventions into elder abuse. Melbourne: NARI/SRV, 2016. Available at https://seniorsrights.org.au/wp-content/ uploads/2016/06/SRV-NARI-Outcomes-Report2016-FINAL-Web-6-June-2016.pdf [Accessed 23 September 2017].

15. Queensland Law Society. QLS announces tria to raise awareness of widespread hidden elder abuse. Brisbane: QLS, June 2017. Available at www.qls.com.au/About QLS/News_media/ News/QLS_announces_trial_to_raise_awareness of_widespread_hidden_elder_abuse [Äccessed 23 September 2017].

16. Health Justice Australia. Health Justice Australia website. NSW: Health Justice Australia, [date unknown]. Available at www.healthjustice.org.au [Accessed 23 September 2017].

17. Justice Connect. Working together: $A$ health justice partnership to address elder abuse First year report. Melbourne: Justice Connect, March 2016. Available at www.justiceconnect. org.au/sites/default/files/HJP_first\%20year\%20 report_web.pdf [Accessed 10 July 2017].

18. Baker PR, Francis DP, Hairi NN, Othman S, Choo WY. Interventions for preventing abuse in the elderly. Cochrane Database Syst Rev 2016;(8):CD010321. doi: 10.1002/14651858. CD010321.pub2.

19. Baker PR, Francis DP, Mohd Hairi NN, Othman S, Choo WY. Interventions for preventing elder abuse: Applying findings of a new Cochrane review. Age Ageing 2017;46(3):346-48. doi: 10.1093/ageing/ afw186.

20. Joosten M, Vrantsidis F, Dow B. Understanding elder abuse: A scoping study. Melbourne: University of Melbourne and the National Ageing Research Institute, 2017. 